\title{
ANALISIS FAKTOR PENYEBAB DAN AKIBAT DARI KETIDAKTEPATAN WAKTU PENYUSUNAN ANGGARAN PENDAPATAN DAN BELANJA DAERAH KABUPATEN BULELENG TAHUN 2017
}

\author{
Komang Ayu Ani Savitri, Made Adwityam Dewantara, \\ Ni Luh Putu Ari Darmayant, Kadek Yanti Kusuma Dewi, \\ Ni Ketut Cahyani Paramita Sari \\ Jurusan Akuntansi, Universitas Pendidikan Ganesha, Singaraja, Bali,Indonesia
}

\begin{abstract}
Abstrak
Peneltian ini bertujuan untuk mengetahui faktor-faktor penyebab terlambatnya penyusunan APBD Kabupaten Buleleng, pengaruh perubahan SKPD terhadap terlambatnya penyusunan APBD, dampak atau implikasi yang ditimbulkan dari terlambatnya penyusunan APBD dan cara mengatasi keterlambatan penyusunan APBD. Dari hasil penelitian pengaruh perubahan SKPD menurut responden perubahan SKPD bisa saja menyebabkan keterlambatan penyusunan APBD, akan tetapi pada penelitian yang diambil ini meskipun memiliki keterkaitan seperti halnya ada kesalahnya perhitungan SKPD namun tidak menghambat penyusunan APBD. Karena jika terjadi kesalahan perhitungan, masih bisa diatasi dengan menghitung ulang. Terdapat beberapa terobosan yang dapat dilakukan untuk mengatasi permasalahan yang muncul dalam penyusunan APBD, yakni:Perlu dilakukan inovasi-inovasi dalam proses perencanaan partisipatif, perlu dikembangkan strategi berupa dialog ataupun sosialisasi mengenai perencanaan dan penganggaran berbasis kinerja, perlu penguatan kapasitas dan komitmen, baik bagi kalangan Pemda maupun DPRD, pemberian sanksi sesuai aturan mesti tetap dijalankan namun dengan sanksi yang lebih spesifik
\end{abstract}

Kata kunci: Anggaran, APBD, SKPD

\section{Abstract}

This research aims to find out the factors that cause the delay in the preparation of the Buleleng Regency APBD, the influence of SKPD changes on the delay in the preparation of the $A P B D$, the impact or implications arising from the delay in the preparation of the $A P B D$ and how to overcome the delay in the preparation of the APBD. From the results of the study the influence of changes in SKPD according to respondents changes in SKPD could have caused delays in the preparation of the $A P B D$, but in this study taken even though it has a connection as well as there is a mistake in calculating the SKPD but does not hamper the preparation of the APBD. Because if a calculation error occurs, it can still be overcome by recalculating. There are several breakthroughs that can be made to overcome the problems that arise in the preparation of the APBD, namely: Innovations in the participatory planning process need to be developed, strategies need to be developed in the form of dialogue or outreach on performance-based planning and budgeting, it needs to strengthen capacity and commitment, both for the community Local government and DPRD, sanctions in accordance with the rules must continue to be carried out but with more specific sanctions.

Keywords : Budget, APBD, SKPD

\section{Pendahuluan}

APBD adalah rencana keuangan tahunan pemerintahan daerah yang dibahas dan disetujui bersama oleh pemerintah daerah dan DPRD, dan ditetapkan dengan peraturan daerah (Sutaryo, Sutopo dan Wijaya, 2014). Undang-Undang No. 32 Tahun 2004 yang merupakan pengganti Undang-Undang No. 22 Tahun 1999 adalah undang-undang yang mengatur tentang pemberlakuan otonomi daerah di Indonesia. Pemberlakuan otonomi 
daerah telah memberikan pemerintah daerah peluang yang lebih besar untuk mengoptimalkan potensi sumber daya manusia, dana maupun kekayaan lainnya .

Kebijakan otonom juga dimaksudkan agar pemerintah daerah dapat mengelola keuangan daerahnya masing-masing. Salah satu aspek penting dalam pelaksanaan otonomi daerah adalah masalah APBD. APBD merupakan dasar pengelolaan keuangan daerah dalam masa 1 (satu) tahun anggaran yang terhitung mulai tanggal 1 Januari sampai dengan tanggal 31 Desember. Dengan demikian, APBD menjadi pedoman bagi pemerintah daerah dalam merencanakan kegiatan pada tahun yang bersangkutan. Fungsi ini menjadikan APBD penting karena kegiatan pemerintah daerah tidak dapat dilaksanakan jika tidak direncanakan dan dicantumkan dalam APBD. Oleh karena fungsi APBD yang sangat penting dalam pengelolaan keuangan daerah, maka proses penyusunan APBD seharusnya menjadi lebih baik dan tepat waktu.

Penetapan APBD harus dilakukan tepat waktu agar program kegiatan dan pembangunan yang direncanakan terealisasi pada tahun anggaran sehingga pemberian pelayanan publik terhadap masyarakat dapat berjalan dengan lancar. Penetapan APBD diatur dalam Peraturan Menteri Dalam Negeri No. 22 Tahun 2011 tentang pedoman penyusunan Anggaran Pendapatan dan Belanja Daerah tahun anggaran 2012, bahwa penetapan APBD 2012 paling lambat tanggal 31 Desember.

Namun demikian, fenomena yang terjadi pemerintah daerah belum mampu memenuhi tenggat waktu sebagaimana diatur di atas. Tercatat pada tahun anggaran 2012, terdapat 234 kabupaten dan kota yang mengalami keterlambatan dalam menetapkan APBD dan tahun anggaran 2013 terdapat 185 kabupaten dan kota yang mengalami keterlambatan (keuda.kemendagri.go.id, Agustus 2013). Selain itu, pada tahun anggaran 2012, terdapat 16 kabupaten yang menetapkan APBD terlambat dan dikenakan sanksi penundaan dana perimbangan dan terdapat 16 kabupaten dan satu kota dikenakan sanksi penundaan dana perimbangan pada tahun 2013.

Kenyataan akan pemerintah daerah yang terlambat menetapkan APBD ini menunjukkan lemahnya kondisi pengelolaan keuangan daerah di Indonesia karena menurut Kementerian Dalam Negeri, salah satu indikator utama untuk mengukur kinerja pengelolaan keuangan daerah adalah ketepatwaktuan dalam penetapan APBD. Fenoma ini tentunya menarik untuk dikaji secara lebih mendalam dalam penelitian. Keterlambatan penetapan APBD ini dapat disebabkan oleh beberapa faktor yaitu kurang harmonisnya hubungan eksekutif dan legislatif, pengaruh dari 3 karakteristik yang dimiliki oleh eksekutif dan legislatif sebagai penyusun APBD serta faktor komitmen yang belum memadai.

Fungsi APBD adalah sebagai perencanaan sekaligus dasar pengelolaan keuangan daerah dalam masa 1 (satu) tahun anggaran, terhitung mulai tanggal 1 Januari sampai dengan 31 Desember. Hal ini berarti bahwa semua kegiatan di pemerintah daerah tidak dapat dilaksanakan apabila tidak direncanakan dalam APBD. Pemerintah dan DPRD merupakan lembaga yang membahas dan memberikan persetujuan atas rencana keuangan Pemerintah Daerah yang dituangkan dalam APBD. APBD yang sudah selesai dibuat kemudian ditetapkan dalam peraturan daerah. Permendagri 2006 pasal 15 menyatakan bahwa penyusunan APBD disesuaikan dengan kebutuhan penyelenggaraan pemerintahan dan kemampuan pendapatan daerah yang mana dokumen ini berfungsi sebagai otorisasi, perencanaan, pengawasan, alokasi, distribusi dan stabilisasi. Dengan demikian fungsi APBD sangat penting dalam pengelolaan keuangan pemerintah daerah. Mengingat pentingnya APBD dalam pemerintah daerah, maka dalam proses penyusunan APBD seharusnya tepat waktu.

Namun demikian, sampai dengan tahun 2013 banyak pemerintah daerah yang mengalami keterlambatan dalam penetapan APBD. Sebagai contoh, pada tahun 2011 bahwa hanya 161 (32\%) pemerintah daerah yang dapat melakukan penetapan APBD secara tepat waktu. Demikian juga pada tahun 2012, dari 503 pemerintah kabupaten/kota, hanya 257 (51\%) saja yang dapat memenuhi tenggat waktu penetapan APBD, sementara sisanya sebesar 246 provinsi (49\%) tidak tepat waktu. Pada tahun 2013, dari 508 pemerintahan kabupaten/kota, hanya 306 (60\%) pemerintahan kabupaten/kota yang dapat menyelesaikan dokumen APBD, tepat pada waktunya. Sementara, ada 202 (40\%) lainya tidak mampu 
memenuhi waktu penetapan APBD. Hal ini menunjukkan bahwa ketepatwaktuan penyusunan APBD belum sesuai dengan harapan pemerintah..

Sebagai akibat dari keterlambatan penetapan APBD ini pergerakan ekonomi pada pemerintah daerah akan terhambat, karena APBD merupakan stimulus penting bagi pertumbuhan ekonomi daerah . www.koran-sindo.com pada hari Kamis tanggal 4 Desember 2014, Direktur Jenderal (Dirjen) Keuangan Daerah Kementerian Dalam Negeri (Kemendagri) Reydonnyzar Moenek menyatakan bahwa :

"Jika sampai 31 Desember ada daerah yang tak juga menetapkan Raperda APBD, sanksinya jelas yakni tidak diberikan hak-hak keuangannya selama enam bulan".

Lebih lanjut, dalam UU No. 23 tahun 2004 tentang Pemerintah Daerah (Pemda) menyebutkan bahwa DPRD dan kepala daerah yang tidak menyetujui bersama Raperda tentang APBD sebelum dimulai tahun anggaran setiap tahun dikenai sanksi administratif berupa tidak dibayarkan hak-hak keuangannya. Hak-hak keuangan yang melekat kepada kepala daerah, wakil kepala daerah dan anggota DPRD itu menyangkut gaji pokok, tunjangan jabatan dan tunjangan lain-lain (UU Nomor 23 tahun 2004 pasal 312 ayat 2).

Dari kasus tersebut diatas, diharapkan tidak ada keterlambatan dalam penetapan APBD, sehingga pergerakan perekonomian yang ada di daerah tidak terhambat dan sanksi administratif tidak dikenakan kepada kepala daerah, wakil kepala daerah dan anggota DPRD. Hal ini sesuai dengan prinsip penyusunan APBD dalam Permendagri No. 22 tahun 2011 yaitu APBD harus disusun secara tepat waktu sesuai tahapan dan jadwal. PP Nomor 60 Tahun 2008 menyatakan bahwa untuk mencapai pengelolaan keuangan negara yang efektif, efesien, transparan, dan akuntabel, menteri/ pimpinan lembaga, gubernur, dan bupati/ walikota wajib melakukan 6 pengendalian atas penyelenggaraan kegiatan pemerintah yaitu dengan membentuk instansi pemerintah yang berpedoman pada Sistem Pengendalian Intern Pemerintah (SPIP).

Sutaryo dan Winarna (2013) menyatakan bahwa ketepatwaktuan penetapan APBD dipengaruhi oleh size pemerintah daerah dan ststus pemerintah daerah. Penelitian serupa juga telah dilakukan oleh Suhardjanto dan Yulianingtyas (2011). Dalam penelitiannya menggunakan variabel ukuran pemerintah daerah, jumlah SKPD dan status daerah sebagai proaksi dari karakteristik pemerintah daerah. Selain itu, penelitian terdahulu mengenai ketepatwaktuan penetapan APBD pernah dilakukan oleh Sutaryo, Sutopo dan Wijaya (2014) yang menggunakan variabel status, ukuran, letak geografis, tipe dan jumlah SKPD pemerintah daerah. Sari dan Witono (2014) menyimpulkan faktor yang mempengaruhi Ketepatwaktuan adalah kemampuan sumber daya manusia, pemanfaatan teknologi informasi, dan pengendalian internal.

Dalam penelitian ini memilih objek penelitian di Pemerintah Kabupaten Buleleng tentang ketidaktepatan waktu dalam penyusunan Anggaran Pendapatan dan Belanja Daerahnya. Peneliti tertarik untuk melakukan penelitian terkait dengan hal tersebut dipengaruhi oleh beberapa faktor yaitu : 1) Keterlambatan dalam penyusunan Anggaran Pendapatan dan Belanja Daerah Kabupaten Buleleng, 2) Terjadinya salah perhitungan SKPD, 3) Terjadinya perubahan SKPD, 4)Pengaruh salah perhitungan SKPD dan perubahan SKPD terhadap keterlambatan penyusunan APBD. Dari Faktor-faktor tersebutlah yang melatarbelakangi peneliti tertarik untuk mengangkat masalah ini, dengan judul "Analisis Faktor Penyebab dan Akibat dari Ketidaktepatan Waktu Penyusunan Anggaran Pendapatan dan Belanja Daerah Kabupaten Buleleng Tahun 2017'.

Berdasarkan latar belakang di atas, penulis memiliki beberapa rumusan masalah yaitu Apakah faktor-faktor penyebab terlambatnya penyusunan APBD Kabupaten Buleleng, Adakah pengaruh perubahan SKPD terhadap terlambatnya penyusunan APBD, Adakah dampak atau implikasi yang ditimbulkan dari terlambatnya penyusunan APBD dan Bagaimana cara mengatasi keterlambatan penyusunan APBD.

\section{Hasil dan Pembahasan}

\subsection{Faktor-Faktor Penyebab Terlambatnya Penyusunan APBD}


Menurut I Dewa Putu Banjar,S.E selaku Kepala Sub Bidang Penyusunan Anggaran, faktor yang menyebabkan terjadinya keterlambatan penyusunan dan penetapan Anggaran Pendapatan dan Belanja Daerah (APBD) adalah sebagai berikut:

\section{Perda Pembentukan APBD yang Belum Ditetapkan}

Tahun anggaran APBD sama dengan tahun anggaran APBN yaitu mulai 1 Januari dan berakhir tanggal 31 Desember tahun yang bersangkutan. Sehingga pengelolaan, pengendalian, dan pengawasan keuangan daerah dapat dilaksanakan berdasarkan kerangka waktu tersebut. APBD disusun dengan pendekatan kinerja yaitu suatu sistem anggaran yang mengutamakan upaya pencapaian hasil kerja atau output dari perencanaan alokasi biaya atau input yang ditetapkan. Jumlah pendapatan yang dianggarkan dalam APBD merupakan perkiraan yang terukur secara rasional yang dapat tercapai untuk setiap sumber pendapatan. Pendapatan dapat direalisasikan melebihi jumlah anggaran yang telah ditetapkan.

Berkaitan dengan belanja, jumlah belanja yang dianggarkan merupakan batas tertinggi untuk setiap jenis belanja. Jadi, realisasi belanja tidak boleh melebihi jumlah anggaran belanja yang telah ditetapkan. Penganggaran pengeluaran harus didukung dengan adanya kepastian tersedianya penerimaan dalam jumlah yang cukup. Setiap pejabat dilarang melakukan tindakan yang berakibat pengeluaran atas beban APBD apabila tidak tersedia atau tidak cukup tersedia anggaran untuk membiayai pengeluaran tersebut.

\section{Cara Penyusunan APBD}

APBD disusun melalui beberapa tahap kegiatan. Kegiatan tersebut, antara lain, sebagai berikut.

- Pemerintah Daerah menyusun Rancangan Pendapatan dan Belanja Daerah (RAPBD).

Pemerintah Daerah mengajukan RAPBD kepada DPRD untuk dibahas bersama antara pemerintah daerah dan DPRD. Dalam pembahasan ini pihak Pemerintah Daerah (Eksekutif) dilakukan oleh Tim Anggaran Eksekutif yang beranggotakan Sekretaris Daerah, BAPPEDA, dan pihak-pihak lain yang dianggap perlu, sedangkan DPRD dilakukan oleh Panitia Anggaran yang anggotanya terdiri atas tiap fraksi-fraksi.

- RAPBD yang telah disetujui DPRD disahkan menjadi APBD melalui Peraturan Daerah untuk dilaksanakan.

\section{PENYUSUNAN APBD}

\section{A. Siklus Anggaran}

APBD merupakan dasar pengelolaan keuangan daerah dalam masa 1 (satu) tahun anggaran terhitung mulai tanggal 1 Januari sampai dengan tanggal 31 Desember. APBD disusun sesuai dengan kebutuhan penyelenggaraan pemerintahan dan kemampuan pendapatan daerah. Dalam pelaksanaan tugas-tugas pemerintahan, pemerintah melaksanakan kegiatan keuangan dalam siklus pengelolaan anggaran yang secara garis besar terdiri dari:

1. Penyusunan dan Penetapan APBD

2. Pelaksanaan dan Penatausahaan APBD

3. Pelaporan dan Pertanggungjawaban APBD.

Penyusunan APBD berpedoman kepada Rencana Kerja Pemerintah Daerah dalam rangka mewujudkan pelayanan kepada masyarakat untuk tercapainya tujuan bernegara. APBD, perubahan APBD, dan pertanggungjawaban pelaksanaan APBD ditetapkan setiap tahun dengan peraturan daerah. Dalam menyusun APBD, penganggaran pengeluaran harus didukung dengan adanya kepastian atas tersedianya penerimaan dalam jumlah yang cukup. Pendapatan, belanja dan pembiayaan daerah yang dianggarkan dalam APBD harus berdasarkan pada ketentuan peraturan perundang-undangan dan dianggarkan secara bruto dalam APBD.

\section{B. Penyusunan Rancangan APBD}

Pemerintah Daerah perlu menyusun APBD untuk menjamin kecukupan dana dalam menyelenggarakan urusan pemerintahannya. Karena itu, perlu diperhatikan kesesuaian antara kewenangan pemerintahan dan sumber pendanaannya. Pengaturan kesesuaian kewenangan dengan pendanaannya adalah sebagai berikut: 
a. Penyelenggaraan urusan pemerintahan yang menjadi kewenangan daerah didanai dari dan atas beban APBD.

b. Penyelenggaraan urusan pemerintahan yang menjadi kewenangan pemerintah pusat di daerah didanai dari dan atas beban APBN.

c. Penyelenggaraan urusan pemerintahan provinsi yang penugasannya dilimpahkan kepada kabupaten/kota dan/atau desa, didanai dari dan atas beban APBD provinsi.

d. Penyelenggaraan urusan pemerintahan kabupaten/kota yang penugasannya dilimpahkan kepada desa, didanai dari dan atas beban APBD kabupaten/kota.

Rancangan peraturan kepala daerah tentang APBD dapat dilaksanakan setelah memperoleh pengesahan dari gubernur bagi kabupaten/kota. Sedangkan pengesahan rancangan peraturan kepala daerah tentang APBD ditetapkan dengan keputusan gubernur bagi kabupaten/kota.

Penyampaian rancangan peraturan kepala daerah untuk memperoleh pengesahan paling lama 15 (lima belas) hari kerja terhitung sejak DPRD tidak menetapkan keputusan bersama dengan kepala daerah terhadap rancangan peraturan daerah tentang APBD.

Apabila dalam batas waktu 30 (tiga puluh) hari kerja gubernur tidak mengesahkan rancangan peraturan kepala daerah tentang APBD, kepala daerah menetapkan rancangan peraturan kepala daerah dimaksud menjadi peraturan kepala daerah.

Khusus untuk pengeluaran, diatur bahwa pelampauan batas tertinggi dari jumlah pengeluaran, hanya diperkenankan apabila ada kebijakan pemerintah untuk kenaikan gaji dan tunjangan pegawai negeri sipil serta penyediaan dana pendamping atas program dan kegiatan yang ditetapkan oleh pemerintah serta bagi hasil pajak daerah dan retribusi daerah yang ditetapkan dalam undang-undang.

\section{Dana Bagi Hasil Dari Provinsi yang Terlambat}

Keterlambatan penyaluran Dana Bagi Hasil (DBH) ke daerah merupakan masalah yang mendesak untuk segera diselesaikan, karena menganggu sistem perencanaan pembangunan daerah. Penyaluran $\mathrm{DBH}$ di beberapa daerah masih mengalami keterlambatan karena dipengaruhi berbagai faktor dalam mekanisme penghitungannya serta data kontraktor kontrak kerja sama (KKKS). Selain itu pemekaran wilayah juga menjadi penyebab keterlambatan DBH SDA. Pemerintah masih terus mengupayakan percepatan $\mathrm{DBH}$ ini.

\section{Kualitas Rencana Pembangunan Jangka Panjang Daerah (RPJPD), Rencana Pembangunan Jangka Menengah Daerah (RPJMD) dan Rencana Strategis (Renstra) SKPD yang belum optimal}

Masih sering ditemui kelemahan dalam dokumen perencanaan yang seringkali tidak sinkron dengan indikator capaian kinerjanya dan sulit untuk diukur. Hal ini dapat dijelaskan karena dalam penyusunan indikator capaian kinerja tersebut terkadang menggunakan asumsi dalam bentuk kalimat-kalimat yang tidak jelas ukurannya, di samping data pendukung yang kurang valid disertai analisa yang kurang tajam. Hal ini akan sangat berpengaruh pada target yang akan dicapai. Indikator kinerja menunjukkan tingkat yang dicapai dari pelaksanaan program dan kebijaksanaan untuk mewujudkan visi, misi, sasaran, tujuan dari organisasi sektor publik. Indikator kinerja memiliki peran penting karena indikator ini berguna dalam penentuan kinerja yang dicapai dari pelaksanaan APBD dan perlu diingat pula bahwa APBD disusun dengan berbasiskan pada kinerja. Indikator kinerja terdiri dari input, output, efisiensi, kualitas, dan outcome

\section{Adanya intervensi pada saat proses penyusunan perencanaan}

Perencanaan suatu kegiatan terutama yang berkaitan dengan peningkatan pembangunan di semua sektor dalam rangka meningkatkan kesejahteraan masyarakat, tentunya diawali dengan perencanaan yang didasari oleh pedoman - pedoman yang ada termasuk rencana strategis yang telah disusun dalam jangka waktu 5 (lima) tahun ke depan tanpa mengesampingkan isu-isu strategis yang ada selama masih berkaitan dan mempunyai output yang jelas. Akan sangat selaras ketika semua bisa mengacu pada pedoman yang ada dan akan sangat mudah nantinya dalam proses monitoring dan evaluasi. Namun jika perencanaan keluar dari pedoman-pedoman strategis yang telah ditetapkan maka daerah 
akan menemui kesulitan dalam menyusun perencanaan program dan kegiatan satu tahun ke depan.

\section{Koordinasi antar SKPD masih lemah}

Koordinasi yang masih sangat minim dilakukan di antara SKPD yang dapat berpengaruh terjadinya masalah dalam penganggaran, misalnya alokasi anggaran menjadi double account atau tumpang tindih dengan program dan kegiatan yang sama pada SKP yang berbeda. Hal ini sering terjadi dikarenakan beberapa faktor antara lain adalah egosektoral yang masih sering ada pada masing-masing SKPD.

Keterpaduan, konsistensi dan sinkronisasi tidak hanya antara aspek perencanaan dengan penganggaran, tetapi juga antar SKPD. Hal ini perlu diperhatikan karena target capaian program dan atau target hasil (outcome) sebuah kegiatan dan atau visi daerah dapat dicapai melalui sinergi program dan kegiatan antar SKPD.

\section{SDM yang kurang kompeten dalam manajemen perencanaan dan penganggaran}

SKPD dengan mayoritas ketenagaannya adalah petugas fungsional, menyebabkan pihak-pihak yang terlibat dalam proses manajemen perencanaan dan penganggaran adalah tenaga fungsional (misalnya tenaga fungsional kesehatan). Hal ini akan sangat berpengaruh pada penjadwalan perencanaan yang sering tidak tepat waktu. Selain itu, SDM dari pihak Bappeda di daerah seringkali kurang paham mengenai program dan kegiatan yang ada pada masing-masing SKPD. Latar belakang pendidikan menunjukkan kemampuan dan bidang ilmu yang dikuasai oleh seseorang selama menempuh jalur pendidikan formal. Bidang ilmu yang dikuasai oleh pihak-pihak yang terlibat dalam penyusunan APBD hendaknya sejalan dengan kegiatan penganggaran. Oleh karena itu, anggota dari organisasi sektor publik khususnya yang terlibat dalam penyusunan APBD hendaknya memiliki dasar ilmu yang berkaitan dengan sistem penyusunan anggaran.

\section{Faktor Team Work dan Komitmen}

Secara normatif, perencanaan dan penganggaran harus terpadu, konsisten dan sinkron satu sama lain. Hal ini harus dilakukan karena penganggaran merupakan media untuk mewujudkan target-target kinerja yang direncanakan. Tanpa perencanaan yang baik, SKPD cenderung tidak fokus serta cenderung bersifat reaktif yang pada akhirnya bermuara pada inefisiensi dan inefektifitas.

Saat penyusunan perencanaan, pimpinan terkadang hanya melibatkan segelintir pegawai saja, sementara perencanaan program dan kegiatan adalah atas nama organisasi, sehingga akan lebih baik apabila keseluruhan proses

penganggaran mulai dari awal perencanaan sampai pada kegiatan monitoring

dan evaluasi terakhir melibatkan seluruh pegawai sebagai team work dalam rangka mencapai tujuan akhir yang akan dicapai oleh organisasi.

Selain itu, pada penyusunan APBD, pihak-pihak yang terlibat hendaknya memiliki komitmen yang tinggi untuk melaksanakan penyusunan APBD secara tepat waktu serta melaksanakan anggaran yang telah ditetapkan dengan efektif dan efisien. Adanya komitmen memberikan gambaran bagi pihak yang terlibat dalam penyusunan APBD untuk mengetahui secara jelas visi, misi, tujuan, dan sasaran yang ingin dicapai dalam penyusunan APBD. Selain itu, melalui komitmen dapat menciptakan motivasi dan kemauan bagi pihak penyusun APBD untuk menyelenggarakan tahapan penyusunan APBD yang lebih baik, efektif, efisien, dan sesuai dengan peraturan yang berlaku.

\section{Intervensi Hak Budget DPRD terlalu kuat}

Anggota DPRD sering mengusulkan kegiatan-kegiatan yang menyimpang jauh dari usulan masyarakat yang dihasilkan dalam Musrenbang. Beberapa faktor-faktor intervensi hak budget DPRD yang dapat menjadi penghambat dalam penyusunan APBD, adalah :

- Usulan dari DPRD yang terkadang tidak sesuai dengan hasil kesepakatan pada saat Musyawarah

- Unsur politis dalam rangka mewujudkan kepentingan tertentu

- Motif pada saat pelaksanaan proyek di lapangan dalam rangka mencari keuntungan pribadi

- Adanya istilah "sinterklas" (bagi-bagi proyek) kepada oknum anggota DPRD atau pejabat daerah 


\section{SDM Evaluasi Anggaran pada Pemerintah Provinsi}

APBD Kabupaten/ Kota wajib dievaluasi oleh Pemerintah Provinsi. Namun kadang pelaksanaan evaluasi ini tidak dibarengi dengan ketersediaan dan kompetensi SDM pada Pemerintah Provinsi yang terlibat saat melakukan evaluasi anggaran.

\subsection{Pengaruh Perubahan SKPD terhadap Keterlambatan Penyusunan APBD}

SKPD (Satuan Kerja Perangkat Daerah) adalah organisasi/lembaga pada pemerintah daerah yang bertanggung jawab kepada gubernur/bupati/walikota dalam rangka penyelenggaraan pemerintahan yang terdiri atas sekretaris daerah, dinas daerah dan lembaga teknis daerah, kecamatan, dan satuan polisi pamong praja sesuai dengan kebutuhan daerah sedangkan APBD (Anggaran Pendapatan dan Belanja Daerah ) juga dikenal dengan Anggaran Daerah adalah suatu bentuk kongkrit rencana kerja keuangan daerah yang komprehensif yang mengkaitkan penerimaan dan pengeluaran pemerintah daerah yang dinyatakan dalam bentuk uang untuk mencapai tujuan atau target yang direncanakan dlaam jangka waktu tertentu dalam satu tahun anggaran.

Menurut Yulin Vidyasari,S.H selaku Kepala Sub Bidang Analisis Kebijakan Keuangan \& Administrasi Anggaran dan Ida Ayu Putu Pastini,S.E APBD dan SKPD sangat berkaitan dan saling berpengaruh, dimana jika terjadinya perubahan SKPD menyebabkan keterlambatan penyusunan APBD, akan tetapi meskipun memiliki keterkaitan ada hal seperti salahnya perhitungan SKPD yang tidak menghambat penyusunan APBD. Karena jika terjadi salahnya perhitungan masih bisa diatasi dengan menghitung ulang, akan tetapi jika terjadi perubahan SKPD maka sudah pasti APBD akan mengalami perubahan pula. Jika perubahan sangat fatal dan belum mendapat solusi maka hal tersebut akan menghambat penyusunan APBD tahun berikutnya. Seperti halnya yang terjadi di Bagian Keuangan Sekretaris Daerah Kabupaten Buleleng, disini mengalami keterlambatan penyusunan APBD dikarenakan perubahan SKPD sehingga pemerintah kabupaten buleleng harus mengubah APBD.

Secara sederhana, perubahan APBD dapat diartikan sebagai upaya pemerintah daerah untuk menyesuaikan rencana keuangannya dengan perkembangan yang terjadi. Perkembangan dimaksud bisa berimplikasi pada meningkatnya anggaran penerimaan maupun pengeluaran, atau sebaliknya. Namun, bisa juga untuk mengakomodasi pergeseran-pergeseran dalam satu SKPD. Perubahan atas setiap komponen APBD memiliki latar belakang dan alasan berbeda. Ada perbedaan alasan untuk perubahan anggaran pendapatan dan perubahan anggaran belanja. Begitu juga untuk alasan perubahan atas anggaran pembiayaan, kecuali untuk penerimaan pembiayaan berupa SiLPA (Sisa Lebih Perhitungan Anggaran Tahun Lalu), yang memang menjadi salah satu alasan utama merngapa perubahan APBD dilakukan.

Perubahan atas pendapatan, terutama PAD bisa saja berlatar belakang perilaku oportunisme para pembuat keputusan, khususnya birokrasai di SKPD dan SKPKD. Namun, tak jarang perubahan APBD juga memuat preferensi politik para politisi di parlemen daerah (DPRD). Anggaran pendapatan akan direvisi dalam tahun anggaran yang sedang berjalan karena beberapa sebab, diantaranya karena

(a)tidak terprediksinya sumber penerimaan baru pada saat penyusunan anggaran,

(b) perubahan kebijakan tentang pajak dan retribusi daerah, dan

(c) penyesuaian target berdasarkan perkembangan terkini.

Terdapat beberapa kondisi yang menyebabkan mengapa perubahan atas Anggaran Pendapatan dan Belanja Daerah terjadi, di antaranya:

1. Target pendapatan dalam APBD underestimated (dianggarkan terlalu rendah). Jika sebuah angkat untuk target pendapatan sudah ditetapkan dalam APBD, maka angka itu menjadi target minimal yang harus dicapai oleh eksekutif. Target dimaksud merupakan jumlah terendah yang "diperintahkan" oleh DPRD kepada eksekutif untuk dicari dan menambah penerimaan dalam kas daerah.

2. Alasan penentuan target PAD oleh SKPD dapat dipahami sebagai praktik moral hazard yang dilakukan agency yang dalam konteks pendapatan adalah sebagai budget minimizer. Dalam penyusunan rancangan anggaran yang menganut konsep partisipatif, SKPD mempunyai ruang untuk membuat budget slack karena memiliki 
keunggulan informasi tentang potensi pendapatan yang sesungguhnya dibanding DPRD.

3. Jika dalam APBD "murni" target PAD underestimated, maka dapat "dinaikkan" dalam APBD Perubahan untuk kemudian digunakan sebagai dasar mengalokasikan pengeluaran yang baru untuk belanja kegiatan dalam APBD-P. Penambahan target PAD ini dapat diartikan sebagai hasil evaluasi atas "keberhasilan" belanja modal dalam mengungkit (leveraging) PAD, khususnya yang terealiasai dan tercapai outcome-nya pada tahun anggaran sebelumnya.

Perubahan atas alokasi anggaran belanja merupakan bagian terpenting dalam perubahan, khususnya pada kelompok belanja langsung. Beberapa bentuk perubahan alokasi untuk belanja modal berrdasarkan penyebabnya adalah:

1. Perubahan karena adanya varian SiLPA. Perubahan harus dilakukan apabila prediksi atas SiLPA tidak akurat, yang bersumber dari adanya perbedaan antara SILPA 201a definitif setelah diaudit oleh BPK dengan SiLPA 201b.

2. Perubahan karena adanya pergeseran anggaran (virement). Pergeseran anggaran dapat terjadi dalam satu SKPD, meskipun total alokasi untuk SKPD yang bersangkutan tidak berubah.

3. Perubahan karena adanya perubahan dalam penerimaan, khususnya pendapatan. Perubahan target atas pendapatan asli daerah (PAD) dapat berpengaruh terhadap alokasi belanja perubahan pada tahun yang sama. Dari perspektif agency theory, pada saat penyusunan APBD murni, eksekutif (dan mungkin juga dengan sepengetahuan dan/atau persetujuan legislatif) target PAD ditetapkan di bawah potensi, lalu dilakukan "adjustment" pada saat dilakukan perubahan APBD.

Perubahan dalam pembiayaan terjadi ketika asumsi yang ditetapkan pada saat penyusunan APBD harus direvisi. Ketika besaran realisasi surplus/defisi dalam APBD berjalan berbeda dengan anggaran ayng ditetapkan sejak awal tahun anggaran, maka diperlukan penyesuaian dalam anggaran penerimaan pembiayaan, setidaknya untuk mengkoreksi penerimaan yang bersumber dari Sisa Lebih Perhitungan Anggaran Tahun Sebelumnya (SiLPA). SiLPA tahun berjalan merupakan SILPA (Sisa Lebih Pembiayaan) tahun lalu. Oleh karena itu, SiLPA merupakan penerimaan pada awal tahun berjalan. Namun, besaran yang diakui pada saat penyusunan APBD masih bersifat taksiran, belum definitif, karena (a) pada akhir tahun lalu tersebut belum seluruh pertanggungjawaban disampaikan oleh SKPD ke BUD dan (b) BPK RI belum menyatakan bahwa jumlah SiLPA sudah sesuai dengan yang sesungguhnya. Selisih (variance) antara SiLPA dalam APBD tahun berjalan dengan Laporan Realisasi Anggaran (LRA) tahun sebelumnya merupakan angka yang menjadi salah satu bahan untuk perubahan anggaran dalam tahun berjalan, terutama dalam bentuk penyesuaian untuk belanja. Jika diterapkan konsep anggaran berimbang (penerimaan sama dengan pengeluaran atau SILPA bernilai nol atau nihil), maka varian SiLPA akan menyebabkan perubahan alokasi belanja.

Kenyataan akan pemerintah daerah dalam keterlambatan menetapkan APBD ini menunjukkan lemahnya kondisi pengelolaan keuangan. Sehingga sangat diperlukan adanya kerjasama seluruh pihak antara pemerintah dengan SKPD agar tidak tercipta lagi hal seperti ini.

\subsection{Dampak Keterlambatan Penyusunan APBD}

Keterlambatan penyusunan APBD itu memiliki dampak yang sangat merugikan bagi semua pihak dari masyarakat maupun pemerintah, seperti yang dijelaskan dibawah ini:

1. Permasalahan timbul ketika keterlambatan penetapan APBD akibatnya kegiatan pembangunan kebupaten terlambat, terlambat dana transfer ke desa, dan kemungkinan terlambatnya pembayaran gaji pegawai.

a. Terlambatnya dana transfer ke desa

Apapun dampak atau implikasi yang akan ditimbulkan, pelaku utama yang merasakan adalah masyarakat, karena apabila dana desa masih kurang otomatis mempengaruhi kinerja operasional dari desa misal :

1. Bidang Pembangunan Desa 
Penggunaan Dana Desa untuk pembangunan desa bertujuan untuk meningkatkan kesejahteraan masyarakat, peningkatan kualitas hidup, serta penanggulangan kemiskinan. Untuk itu, penggunaan Dana Desa untuk pembangunan desa diarahkan pada program-program seperti:

1. pembangunan, pengembangan, dan pemeliharaan infrastruktur atau sarana dan prasarana fisik untuk penghidupan, termasuk ketahanan pangan dan permukiman.

2. pembangunan, pengembangan, dan pemeliharaan sarana dan prasarana kesehatan masyarakat.

3. pembangunan, pengembangan dan pemelliharaan sarana dan prasarana pendidikan, sosial dan kebudayaan.

4. pengembangan usaha ekonomi masyarakat, meliputi pembangunan dan pemeliharanaan sarana produksi dan distribusi.

5. pembangunan dan pengembangan sarana prasarana energi terbarukan serta kegiatan pelestarian lingkungan hidup.

2. Bidang Pemberdayaan Masyarakat Desa

Prioritas penggunaan Dana Desa 2016 di bidang pemberdayaan masyarakat desa bertujuan untuk meningkatkan kapasitas warga dalam pengembangan wirausaha, peningkatan pendapatan, serta perluasan skala ekonomi individu warga, kelompok masyarakat, antara lain:

1. peningkatan investatsi ekonomi desa melalui pengadaan, pengembangan atau bantuan alat-alat produksi, permodalan, dan peningkatan kapasitas melalui pelatihan dan pemagangan;

2. Dukungan kegiatan ekonomi baik yang dikembangkan oleh BUMDesa atau BUMDesa Bersama, maupun oleh kelompok dan/atau lembaga ekonomi masyarakat desa lainnya.

3. bantuan peningkatan kapasitas untuk program dan kegiatan ketahanan pangan Desa;

4. pengorganisasian masyarakat, fasilitasi dan pelatihan paralegal dan bantuan hukum masyarakat desa, termasuk pembentukan kader pemberdayaan masyarakat desa dan pengembangan kapasitas ruang belajar masyarakat di desa;

5. promosi dan edukasi kesehatan masyarakat serta gerakan hidup bersih dan sehat, termasuk peningkatan kapasitas pengelolaan Posyandu, Poskesdes, Polindes dan ketersediaan atau keberfungsian tenaga medis/swamedikasi di desa;

6. dukungan terhadap kegiatan pengelolaan Hutan/Pantai/Desa dan Hutan/Pantai Kemasyarakatan;

7. peningkatan kapasitas kelompok masyarakat untuk energi terbarukan dan pelestarian lingkungan hidup; dan/atau

8. bidang kegiatan pemberdayaan ekonomi lainnya yang sesuai dengan analisa kebutuhan desa dan telah ditetapkan dalam musyawarah desa.

b. Terlambatnya pembayaran gaji pegawai

Pemerintah mulai menerapkan sanksi bagi daerah yang terlambat menetapkan anggaran pendapatan dan belanja daerah (APBD). Sanksi tersebut diberikan dengan ada penundaan pencairan gaji pokok dan tunjangan kepala daerah dan anggota. DPRD. Direktur Jenderal (Dirjen) Keuangan Daerah (Keuda) Kementerian Dalam Negeri (Kemendagri) Reydonnyzar Moenek mengatakan bahwa pihak mereka masih menahan gaji penjabat sebelum ada petunjuk oleh Kemendagri. Gaji pokok dan tunjangan jabatan hak-haknya belum dibayarkan, lebih lanjut Reydonnyzar mengatakan, dalam UU 23/2014 Pasal 321 ayat 2 jelas disebutkan DPRD dan kepala daerah yang terlambat akan dikenai sanksi administratif berupa tidak dibayarkan hak-hak keuangan yang diatur dalam ketentuan peraturan perundang-undangan selama enam bulan. Namun, sanksi keras tersebut belum diterapkan. Pihaknya hanya melakukan penahanan pencairan gaji. Apalagi, saat ini belum ada petunjuk dari mendagri terkait peraturan pemerintah tentang 
sanksinya. Sesuai Pasal 353 bahwa ketentuan lebih lanjut mengenai tata cara penjatuhan sanksi administratif dan program pembinaan khusus bidang pemerintahan diatur dengan peraturan pemerintah. Kemendagri ini memastikan, jika PP sanksi diterbitkan, tidak ada toleransi bagi daerah yang terlambat menetapkan APBD. Apabila gaji jabatan (gaji atasan) ditunda atau ditahan maka otomatis mempengaruhi gaji pegawai bawahan juga ditunda dan gaji mereka masih masuk di kas daerah.

2. Selain itu manfaat dari dana APBD tert bisa dirasakan masyarakat menjadi tertunda. Seperti yang telah diketahui bahwa APBD merupakan agenda operasional pemerintah. Dalam dokumen tersebut termuat prioritas-prioritas pembangunan, terutama prioritas kebijakan dan target yang akan dicapai sesuai resources atau sumber daya. Program yang terlambat dilaksanakan dapat berpengaruh pada pelayanan publik terhadap masyarakat. Kondisi ini memiliki efek domino lainnya yang dirasakan oleh masyarakat. Persoalan dalam APBD adalah siklus, mulai dari perencanaan, pembahasan, perubahan, pengesahan sampai pelaksanaan anggaran dan perubahan anggaran.

3. Masalah lain yang dirasakan juga oleh masyarakat adalah berkurangnya jatah yang seharusnya diterima. Hal ini terkait dengan adanya sanksi pemotongan DAU atau tertundanya pencairan karena daerah terlambat menyerahkan APBD-nya.. Penundanaan pencairan juga akan menyebabkan ketergesaan dalam melaksanakan kegiatan yang dibiayai oleh anggaran. Sebagai contoh adalah kegiatan pembangunan gedung rumah sakit. Terjadinya penundaan pencairan mengakibatkan pelaksanaan kegiatan tersebut tidak maksimal karena rendahnya kualitas pembangunan dan perawatan insfrastruktur.

Contoh lain misalnya petani ingin membeli pupuk, uang tidak ada. Padahal petani sudah masuk musim tanam. Rumah sakit ingin membeli obat tidak bisa karena anggarannya tidak ada, . Apabila seperti ini masyarakatnya yang sangat dirugikan dirugikan.

4. APBD yang terlambat disahkan oleh pemerintah daerah dan DPRD dapat pula memberi peluang munculnya korupsi, sebagaimana dinyatakan (KPK,2008). Peluang korupsi tersebut dapat muncul dikarenakan adanya usaha untuk mengalihkan dana yang tersisa dari pelaksanaan program APBD ke dalam rekening pribadi. Dana yang tersisa berasal dari dana sisa anggaran program yang tidak selesai dilakukan karena terlambat dalam pelaksanaan proses awal. Pengalihan dana ke rekening pribadi tersebut membuka peluang terjadi penyelewengan dana APBD untuk kepentingan pribadi sehingga terjadilah korupsi. Pada akhirnya dampak yang muncul dari keterlambatan penyusunan APBD tersebut merugikan masyarakat.

5. Permasalahan lainnya adalah dari internal dimana dalam Pemerintah Daerah setiap tahunnya selalu diadakan restrukturisasi pegawai. Hal ini menjadi permasalahan internal yang menyebabkan kurangnya tenaga yang fokus dalam penyusunan APBD ini. Hal ini menjadi masalah yang cukup serius karena pegawai Pemerintah Daerah dituntut memiliki kemampuan yang sesuai bidangnya. Sementara, banyak di daerah yang memiliki latar belakang berbeda dengan pekerjaannya. Kondisi ini ditambah pula dengan adanya mutasi pegawai sehingga membuat proses penyusunan APBD dimulai lagi dari nol karena adanya SDM baru sementara SDM lama yang menangani dipindahkan ke dinas lain dengan jenis pekerjaan yang berbeda.

\subsection{Cara Mengatasi Keterlambatan Penyusunan APBD}

Terdapat beberapa terobosan yang dapat dilakukan untuk mengatasi permasalahan yang muncul dalam penyusunan APBD, yakni:

1. Perlu dilakukan inovasi-inovasi dalam proses perencanaan partisipatif sedemikian rupa sehingga aspirasi-aspirasi politik diyakini benar-benar terserap dalam dokumen perencanaan. Dengan demikian, pembahasan rancangan APBD dapat lebih terfokus pada besaran dana yang seharusnya dialokasikan dan tidak lagi terlalu terbebani dengan transaksi-transaksi politik.

2. Perlu dikembangkan strategi berupa dialog ataupun sosialisasi mengenai perencanaan dan penganggaran berbasis kinerja. Tujuan utama dilakukannya langkah ini adalah untuk mengubah paradigma tradisional yang berfokus pada penganggaran uang menjadi paradigma yang berbasis kinerja yang menitikberatkan pada perencanaan 
kegiatan yang menjawab akar permasalahan di masyarakat.

3. Perlu penguatan kapasitas dan komitmen, baik bagi kalangan Pemda maupun DPRD. Pada umumnya Pemda yang mengalami keterlambatan APBD adalah daerah tertinggal, sehingga perlu fasilitasi dan pengawasan lebih intensif dari Pemprov maupun Pemerintah Pusat. Namun sebenarnya yang utama adalah komitmen, dan justru inilah yang paling sulit. Proses politik berbiaya tinggi barangkali menjadi akar masalah kenapa seringkali anggota dewan (begitu pula Kepala Daerah) bernafsu besar ingin menguasai anggaran.

4. Pemberian sanksi sesuai aturan mesti tetap dijalankan namun dengan sanksi yang lebih spesifik. Pemda wajib menyampaikan Perda kepada Menteri Keuangan maksimal tanggal 20 Maret. Bagi yang terlambat, penyaluran Dana Alokasi Umum (DAU)-nya ditunda 25 persen per bulan. atau Sanksi penghentian pemberian DAU dirubah dengan sanksi penundaan pembayaran tunjangan pejabat pemerintah dan anggota DPRD.

Adapun sanksi untuk keterlambatan penyususnan APBD yaitu sebagai berikut :

Berdasarkan Undang-undang Nomor 23 Tahun 2014 Tentang Pemerintahan Daerah, dalam ketentuan Pasal 311 ayat:

1. Kepala daerah wajib mengajukan rancangan Perda tentang APBD disertai penjelasan dan dokumen-dokumen pendukungnya kepada DPRD sesuai dengan waktu yang ditentukan oleh Peraturan Perundang-undangan untuk memperoleh persetujuan bersama.

2. Kepala daerah yang tidak mengajukan rancangan Perda tentang APBD sebagaimana dimaksud pada ayat (1) dikenai sanksi administrative berupa tidak dibayarkan hak-hak keuangannya yang diatur dalam ketentuan Perundang-undangan selama 6 (enam) bulan.

Sedangkan pada ketentuan Pasal 312, dalam ayat

1. Kepala daerah dan DPRD wajib menyetujui bersama rancangan Perda tentang APBD paling lambat 1 (satu) bulan sebelum dimulainya tahun anggaran setiap tahun.

2. DPRD dan Kepala daerah yang tidak menyetujui bersama rancangan Perda tentang APBD sebelum dimulainya tahun anggaran setiap tahun sebagaimana dimaksud ayat (1) dikenai sanksi administratif berupa tidak dibayarkan hak-hak keuangan yang diatur dalam ketentuan perundang-undangan selama 6 (enam) bulan.

3. Sanksi sebagaimana dimaksud pada ayat (2) tidak dapat dikenakan kepada anggota DPRD apabila keterlambatan penetapan APBD disebabkan oleh Kepala daerah terlambat menyampaikan rancangan Perda tentang APBD kepada DPRD dari jadwal yang telah ditetapkan berdasarkan ketentuan Peraturan Perundang-undangan.

\section{Simpulan dan Saran}

Berdasarkan hasil penelitian dan pembahasan maka dapat disimpulkan bahwa keterlambatan dalam penetapan Anggaran Pendapatan dan Belanja Daerah di Singaraja Tahun 2016 karena adanya faktor-faktor diantaranya sebagai berikut:

1. Perda pembentukan APBD yang belum ditetapkan

2. Dana bagi hasil dari Provinsi yang terlambat

3. Pelaksanaan pendekatan parsitipatif dalam perencanaan melalui mekanisme musrenbang yang belum maksimal

4. Kualitas Rencana Pembangunan Jangka Panjang Daerah (RPJPD), Rencana Pembangunan Jangka Menengah Daerah (RPJMD) dan Rencana Strategis (Renstra) SKPD yang belum optimal

5. Adanya intervensi pada saat proses penyusunan perencanaan

6. Koordinasi antar SKPD masih lemah

7. SDM yang kurang kompeten dalam manajemen perencanaan dan penganggaran

8. Faktor Team Work dan Komitmen

9. Intervensi Hak Budget DPRD terlalu kuat

10. SDM Evaluasi Anggaran pada Pemerintah Provinsi

Disini kami memfokuskan pada pengaruh perubahan SKPD menurut responden perubahan SKPD bisa saja menyebabkan keterlambatan penyusunan APBD, akan tetapi 
pada penelitian yang diambil ini meskipun memiliki keterkaitan seperti halnya ada kesalahnya perhitungan SKPD namun tidak menghambat penyusunan APBD. Karena jika terjadi kesalahan perhitungan, masih bisa diatasi dengan menghitung ulang.

Menurut responden Keterlambatan Penyusunan APBD memberikan dampak kepada yang meresahkan masyarakat karena apabila terlambat maka kegiatan pembangunan kebupaten terlambat, terlambat dana transfer ke desa, dan kemungkinan terlambatnya pembayaran gaji pegawai.

Terdapat beberapa terobosan yang dapat dilakukan untuk mengatasi permasalahan yang muncul dalam penyusunan APBD, yakni:

1. Perlu dilakukan inovasi-inovasi dalam proses perencanaan partisipatif sedemikian rupa sehingga aspirasi-aspirasi politik diyakini benar-benar terserap dalam dokumen perencanaan.

2. Perlu dikembangkan strategi berupa dialog ataupun sosialisasi mengenai perencanaan dan penganggaran berbasis kinerja.

3. Perlu penguatan kapasitas dan komitmen, baik bagi kalangan Pemda maupun DPRD.

4. Pemberian sanksi sesuai aturan mesti tetap dijalankan namun dengan sanksi yang lebih spesifik

Berdasarkan simpulan di atas terdapat saran berupa faktor keterlambatan penyusunan APBD dan analisis yang telah dilakukan sebelumnya maka kami memiliki beberapa saran untuk mengatasi keterlambatan APBD tersebut :

Pertama, perlu dilakukan tindakan yang disiplin dari pihak-pihak penjabat misal baik itu DPRD dan pemerintah daerah lainnya untuk menjadwalkan penyusunan APBD sesuai dengan peraturan penyusunan APBD yaitu Peraturan Menteri Dalam Negeri Nomor 13 Tahun yang telah disempurnakan dengan Peraturan Menteri Dalam Negeri Nomor 59 Tahun 2007 dan Peraturan Menteri Dalam Negeri Nomor 21 Tahun 2011.

Kedua, Persoalan dalam APBD adalah siklus, mulai dari perencanaan, pembahasan, perubahan, pengesahan sampai pelaksanaan anggaran dan perubahan anggaran. Oleh karena itu, dibutuhkan manajemen koordinasi yang baik antar berbagai pihak yang berkepentingan dalam penyusunan APBD.

Ketiga, perlu dikembangkan strategi yang jitu baik berupa dialog ataupun sosialisasi mengenai perencanaan dan penganggaran berbasis kinerja. Tujuan utama dilakukannya langkah ini adalah untuk mengubah paradigma tradisional yang berfokus pada penganggaran uang menjadi paradigma yang berbasis kinerja yang menitikberatkan pada perencanaan kegiatan yang menjawab akar permasalahan di masyarakat.

Keempat, Dalam Permendagri Nomor 13 Tahun 2006 tentang Pedoman Pengelolaan Keuangan Daerah yang diperbaharui dengan Permendagri Nomor 59 Tahun 2007 dan Permendagri Nomor 21 Tahun 2011dituntut pembuatan rencana anggaran secara detil. Dengan penyusunan APBD yang harus sesuai dengan peraturan tersebut maka dibutuhkan jumlah aparatur pemerintahan daerah yang menguasai secara matang tentang keuangan dan penganggaran

Di sini juga kami mengharapkan kepada teman-teman pembaca atau pun di lain pihak agar memberikan suatu masukan atau hal-hal yang berkaitan dalam penulisan makalah ini, karena disini kami membutuhkan kritik dan saran untuk membangun atau memberikan motivasi ke depanya agar dalam pembuatan makalah selanjutnya bisa sempurna.

\section{Daftar Pustaka}

Aristya Prayudi, Made dan Komang Adi Kurniawan Saputra. 2016. Akuntansi Pemerintahan. Singaraja : Istiqlal

http://metrontb.com/dprd-buleleng-gelar-rapat-apbd-perubahan-2016/

http://kamuskeuangandaerah.com/images/artikel/Keterlambatan\%20APBD.pdf

http://kampus4u.blogspot.com/2015/11/permasalahan-umum-dan-klasik-

dalam.html?m=1

http://wacana.ub.ac.id/index.php/wacana/article/view/289

http://googleweblight.com/?lite_url=http://jateng.tribunnews.com/2014/01/16/ini-

dampak-negatif-lambatnya-penetapan-apbd\&ei=8L52W88z\&IC=id- 
Jurnal IImiah Akuntansi dan Humanika, Vol. 9 No. 1, April 2019 ISSN: 2599-2651

ID\&s=1\&m=609\&host=www.google.co.id\&ts=1484464350\&sig=AF9NednbWbqXtRMqX mZemKBSjzfxL1K_og 